\title{
Floriculture as a Profession: Demographic Factors Affecting Floriculture Business in Sikkim
}

\author{
Manjari Sharma ${ }^{1}$ and Shailendra Kumar ${ }^{2}$ \\ ${ }^{1}$ Research Scholar, ${ }^{2}$ Assistant Professor \\ ${ }^{1 \& 2}$ Department of Management, Sikkim University, Sikkim, India \\ E-Mail: manzary13@gmail.com, skumar@cus.ac.in
}

\begin{abstract}
Over the past couple of years, great emphasis has been given to the floriculture sector in the state of Sikkim. It has a great impact in the lives of the local farmers and has been taken up as a profession by many in the state. It is not a great surprise that floriculture is rapidly rising up to become one of the biggest industries in the state as well as the entire country. Sikkim has also garnered a name for itself in the international front in the field of floriculture. Hence, this paper attempts to study the demographic factors that affect the farmers in Sikkim in choosing floriculture practice as their profession. Further, this paper is based on primary data collected within the state. The study explores the sociodemographic factors that anchor profession choices among farmers. For the purpose of this study, a questionnaire was used to collect data and response frequencies and corresponding percentages were calculated and analyzed. Keywords: Floriculture, Demographic Factors, Profession
\end{abstract}

\section{INTRODUCTION}

The art and knowledge of growing flowers to perfection is what floriculture stands for. It includes cultivation of flowering and ornamental plants that are for sale or is used as raw materials for various sectors like pharmaceuticals, cosmetics and perfume industry as well. It has now gained the status of being one of the most productive enterprises for a business to trade in globally and has been deemed to be the fastest growing sectors of agriculture. Globalization has had a vital role to play and its effect on income enhancement, rise in the per capita consumption of the floricultural products in various regions of the world can also be said to be the primary cause of such a rise in the status of the floriculture industry. Traditional flowers like roses, marigold, tuber rose, jasmine, and chrysanthemum still dominate the Indian market (Choudhary, 2008) but there are other varieties of flowers rapidly climbing the stairs to being successfully traded in the global market.

According to a study conducted by Evers et al., (2014), Europe accounted for $2 / 3^{\text {rd }}$ of the value of global cuttings imports. Germany topped the list of being the largest European cuttings importer with an approximately 20\% share. India is an agrarian economy where majority of the population reside in the rural areas. It has also had a long history in growing flowers that decorated the elite palaces and often exported. Hence, flower growing can be termed as an age old enterprise. As per National Horticulture Board during 2015-16, the area under floriculture production in
India was 249 thousand hectares with a production of 1659 thousand tones loose flowers and 484 thousand tones cut flowers in 2015-16.

Agricultural and Processed Food Products Export Development Authority (APEDA), is responsible for export promotion and development of floriculture in India. The Ministry of Commerce and Industry, Government of India shows that the total floriculture products exported by the country is 20703.46 MT to the world for the worth of Rs. 507.31 crores / 78.73 USD millions in 2017-18. This goes on to prove that India is rapidly growing in this department to meet the demand of flowers in the global scenario. The major export destinations for the year 2017-18 were USA, Netherlands, United Kingdom, Germany and UAE. These were also the major importing countries of Indian floriculture during the same period.

With changing life styles and enhanced urban affluence, floriculture in India has gained a definite commercial status in recent times especially in the past three decades. Appreciation of the potential of commercial floriculture has resulted in the blossoming of this field into a viable agribusiness option. Availability of natural resources like diverse agro-climatic conditions permit production of a wide range of temperate and tropical flowers, almost all through the year in some part of the country or other. Developed communication facilities have increased their availability in every part of the country. The commercial activity of production and marketing of floriculture products is also a basis of gainful and quality employment to thousands of people in India.

According to APEDA (2019), floriculture is now commercially cultivated in several states with Tamil Nadu (20\%), Karnataka (13.5\%), West Bengal (12.2\%), having gone ahead of other flower-producing states like Madhya Pradesh, Mizoram, Gujarat, Andhra Pradesh, Orissa, Jharkhand, Haryana, Assam and Chhattisgarh. The important floricultural crops in the international cut flower trade are rose, carnation, chrysanthemum, gerbera, gladiolus, gypsophila, orchids, anthurium, tulip, lilies and many more. Sikkim is one of the biodiversity rich states of our country. It is the second smallest state of India having an area of around $7096 \mathrm{sq} . \mathrm{km}$ and is often termed as the paradise of naturalists. Over the past couple of years great emphasis has been applied to floriculture in the state. It has 
had a great impact in the lives of the local farmers and it can now be said that it is one of the most recent additions to the commercial sector of the agriculture industry.

Today the state has gained international recognition in the field of floriculture. Out of the 34 biodiversity hotspots in the world recognized by UNESCO (The United Nations Educational, Scientific and Cultural Organization), India owns two, of which Sikkim (Eastern Himalaya) is one of them. Widely held as a botanists' paradise, with variations in the agro-ecological situation, which ranges from hot, humid subtropical climate in the foothills to cold, dry, alpine climate in the higher altitudes, the region has ample scope for the development of floriculture.

Sikkim has also garnered a reputation for growing exclusive flowers with wide varieties and species. The flowers grown in Sikkim are of international recognition and have often been showcased in the flower shows that attract different countries as well as flower exhibition from the whole country. Great importance has been given to floriculture in the state over the past two decades which has resulted in impressive results for this particular sector. The Gazetteer of Sikkim (2018), reports to have around 4458 species of flowering plants. These species are represented under 197 families and 1371 genera. Pedicularis, Primula, Rhododendron, Juncus, Dendrobium, Bulbophyllum, Gentiana are some dominant species of flowering plants found in Sikkim (Acharya \& Sharma, 2013). There are 65 species of vascular plants that have been named after Sikkim as these species are known to have been found first in Sikkim. Naming the flowering plants after Sikkim just goes to second the fact that Sikkim has unparalleled any other state of the country reflecting its richness and uniqueness of the floral diversity. Floriculture and tourism sector rules the business practices of Sikkim. The government also has played a predominant role in bringing floriculture to limelight. The policies and regulations that the government of the state has come up with make it extremely easy for any locals of the state to actually make a living from this sector.

This present study implores the demographic factors that influence the people of the state to take up floriculture practice as a profession. Many educated youths have also taken up floriculture business instead of considering for a government or a corporate service. This has further led to the practice of self-empowerment among many individuals and farmers. The mere idea of taking up floriculture business as a chosen profession is greatly influenced by many demographic factors like age, gender, education level etc.

\section{RESEARCH METHODOLOGY}

\section{A. Scope of the Study}

One vital prerequisite of any study that is being undertaken is a clear statement of objectives. This helps shape the study and gives a certain direction that the researcher needs to follow. This study investigates the socio demographic factors and its effect on farmers choosing floriculture as a profession. This study further covers the farmers that have settled in the South, West and East district of Sikkim (primarily the floriculture dominant hubs inclusive of more than 18 villages). For the purpose of this study, the following objective has been framed:

1. To explore the effect of demographic factors that influences the profession choices of the farmers in the floriculture business in Sikkim.

Along with the primary data collection, journals, books, reports, articles, internet sources have also been made use of. The reason in choosing these districts is that floriculture practices are quite high and successful in these areas. The west district is particularly famous for its rose production. The data obtained from these surveys were analyzed using statistical methods and programs. Analysis also has been done and several comparisons were made with the data that were obtained.

\section{B. Sample Selection and Respondent}

For the study, a total of 83 farmers were selected using purposive sampling approach from the east, west and south districts of Sikkim. The respondents of the study were farmers who were into flower cultivation and marketing. The instrument of the study was administered to the respondents by 'survey' method. The Statistical Package for Social Science (SPSS) was used to analyze the data. The valid samples completed by the farmers were a total of 83 from various districts and villages indicating a response rate of 100 percent.

\section{Research Instrument}

The survey questionnaire was divided into two sections. The first part consisted of respondents' demographic attributes i.e., age, gender, education level etc., While the second part consisted of questions on the 4 Ps of marketing mix (product, price, place \& promotion). The kind of flowers grown and the price at which those were sold et cetera.

\section{RESULTS}

While much attention has been devoted to business skills and the problems faced by the farmers in producing and marketing the flowers, small attention has been paid to demographic factors. The purpose of this study primarily was to examine the effect the demographic variables have on the profession choices of the farmers in Sikkim taking up floriculture practice. To deal with the objective of the study the data collected have been studied and analyzed using the appropriate tools.

\section{A. Demographic Profile of Respondents}

1. Gender: Fig.1 represents the demographic status of the respondents. It can be seen that for a total of 83 farmers, 85.5 percent belong to the male category whereas only 14.4 
percent are females. On further study it showed that the women only took up floriculture practice in Sikkim as a part time business and nothing more and hence the huge gap between the male-female floriculture practices. The women weren't willing to risk taking up floriculture as a profession.

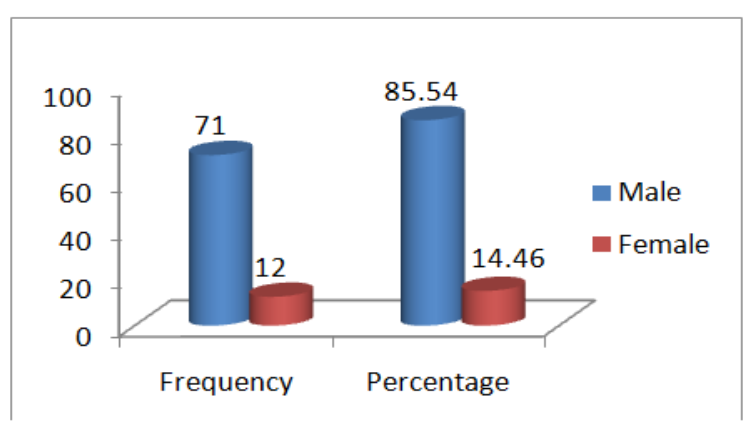

Fig. 1 Gender Distribution

Gender is the state of being male or female in relation to the social and cultural roles that are considered appropriate for men and women. In simple terms, it is the state of being male or female with reference to socially and culturally defined characteristics of masculinity and femininity. This further explains the lack of women involvement in the male dominated sector i.e., floriculture business in Sikkim.

According to Bonnie and Smith, gender theory proposed looking at masculinity and femininity as sets of mutually created characteristics shaping the lives of men and women. A French philosopher, Simone de Beauvoir, made a perceptive statement on gender studies; "One is not born, but rather becomes, a woman". This theory discussed the making of a woman. According to her view, women (unlike men) acted in accordance with men's view of them and not according to their own lights. All of these theories only go on to show how women have lesser freedom in opting for their own profession even in this $21^{\text {st }}$ century. Due to the still prevalent socio-cultural values and norms, the male population has more liberty in deciding their own profession.

According to Agoramoorthy \& Hsu (2012), in contrary to all other studies, this study indicated the involvement of women to a much higher extend in the floriculture practices. It can be seen that much of rural women's work has not been accounted in official data base and there are issues of serious under estimation in case of data collection. In the same study, it states that the Indian agriculture and allied industrial sectors employ $89.5 \%$ of total female labour force as surveyed by FAO in 2008.

2. Age: Besides gender, age profiles are also imperative in taking up floriculture profession. Age of the farmer is another variable in explaining the farmers' aptitude towards the floriculture business as his way of living. It plays an essential role and helps in influencing the farmers' information and determining their ability to convert the available information to a logical act.
In the study conducted, it can be perceived that most people taking up floriculture practice were mostly middle aged or elder people. This situation reveals information about people's willingness to take risks. Most take up floriculture practice as a secondary job. If the person is retired or into some government service or takes it as a predecessor job, they are willing to take up floriculture as a part time profession.

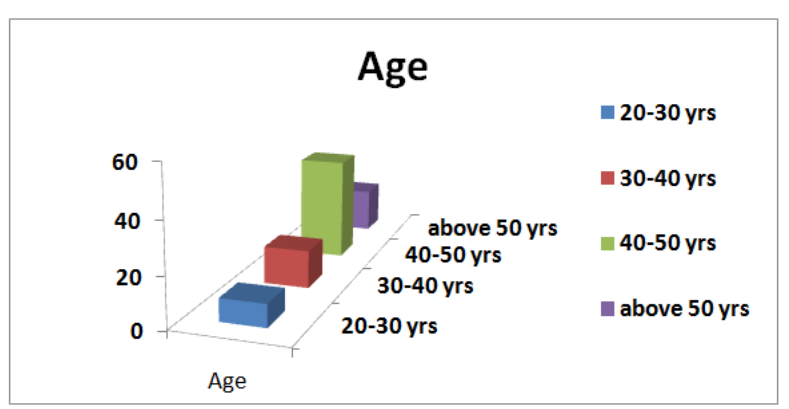

Fig. 2 Age Distribution

The study categorized the age level into four classes: the first category were the younger budding farmers and florists ( 20 - 30 years old), farmers from $30-40$ years belonged to the second category, florist in the $40-50$ years fell in the third category and the last category belong to farmers/ florists who were above 50 years of age. As seen in Table I, $9.64 \%$ fall in the first category, $19.28 \%$ fall in the second, $49.4 \%$ belong to the third category and $21.69 \%$ fall in the last category.

TABLE I Age Distribution Of THE RESPONDENTS

\begin{tabular}{|l|c|c|}
\hline \multicolumn{1}{|c|}{ Age } & No. of Respondents & \% of Respondents \\
\hline $20-30$ & 8 & 9.64 \\
\hline $30-40$ & 16 & 19.28 \\
\hline $40-50$ & 41 & 49.40 \\
\hline above 50 & 18 & 21.69 \\
\hline Total & 83 & 100 \\
\hline
\end{tabular}

It was further revealed that the young farmers were more likely to adapt to new technology and ventured into different sectors like marketing to elite classes and exports. This can be attributed to the fact that they are better versed and educated enough to understand the need for marketing and taking up floriculture profession to a different level. All of these resultantly help them to become more successful in the profession that they choose. The biggest category the florists fell into was the age group of 40-50 years. These farmers were more comfortable in their choice of floriculture as their profession and did it with dedication.

Lin \& Wang, (1991) studied the flower cultivation in Taiwan and concluded that the problems faced by the florists were lack of adequate division of resources and the advanced age of the rural community labour available which led to decreased production. This study also revealed that the younger farmers were willing to take up risks and 
were innovative which led them to make informed and appropriate decisions regarding the business of the floriculture business. The cause can be relatively attributed to the fact that they are more acquainted to extra information than the older farmers in the floriculture sector.

3. Education Level: Education status of a person is also a common and a vital variable that is found to explain a person's choice of profession. The study conducted on the farmers revealed that the more educated florists were the ones who were more compelling and innovative in this profession. They were found to be even more dedicated in what they do than those less educated elder men who were practicing floriculture business for many years.

The educated florists showed tendencies of taking more risks and had enhanced practical awareness and understanding of the market. They grabbed opportunities for various projects and even were seen to showcase their flowers more often in the International Flower Shows that are regularly organized in the state that attracts tens of thousands of people. In a manner of speaking, with the general societal norms, it is normally expected that the level of education is equal to the type of profession. Yet education level isn't as important a factor as gender or age when it comes to accepting floriculture business as a career choice.

The Table II below shows the education level of the respondents of the study. More than $50 \%$ of the farmers were drop-outs and had only done primary schooling. The younger farmers belonged to the most-educated category and had completed their graduation but constituted of only $8 \%$ of the entire population.

TABLE II EDUCATION LEVEL Of THE RESPONDENTS

\begin{tabular}{|l|c|c|}
\hline Education Level & $\begin{array}{c}\text { No. of } \\
\text { Respondents }\end{array}$ & $\begin{array}{c}\text { \% of } \\
\text { Respondents }\end{array}$ \\
\hline Primary & 44 & 53.01 \\
\hline Secondary & 18 & 21.69 \\
\hline Higher Secondary & 14 & 16.87 \\
\hline Graduates & 7 & 8.43 \\
\hline Total & 83 & 100 \\
\hline
\end{tabular}

It is seen that people acquiring floriculture business are mostly primary and secondary level school dropouts. The reason behind this may be because of lack of courses related to floriculture or lack of training in such areas. In a study conducted in Bangalore for floriculture practicing farmers by Joseph et al., (2016), 66.7\% hadn't received any formal education.

In the same study, of all the workers $1.6 \%$ belonged to the lower middle, $26.4 \%$ belonged to the upper middle, $1.6 \%$ belonged to the high school and higher secondary, and $3.9 \%$ belonged to the graduate and above category of education respectively.

\section{CONCLUSION}

While on a search for a profession, it is basic human nature to consider all variable and yet demographic factors aren't given the importance that it actually deserves. This study conducted shows exactly how factors like age, gender, education level affects a person's choice in taking up floriculture practice professionally. Out of the 83 farmers' survey done in the south, east and west district of Sikkim, it can be seen that the male population takes precedence even in this sector like all the other professions. The female florists also have lesser knowledge as to the marketing and other information as opposed to the male florists. The gender gap between the two sexes is quite considerable.

Though many people are nostalgic about floriculture, there are others who brush away the idea as a luxury or even wastage of money. But the significance and the importance of floriculture cannot be brushed off so easily or ignored altogether. Flowers symbolize purity, beauty, peace, love and passion. The potential of floriculture as an industry has not been exploited properly. Floriculture is an intensive type of agriculture and the income per unit area from floriculture is much higher than any other branch of agriculture.

A study by Karthikeyan \& Chandrakandan (2000), revealed that the major problem faced by cut flower growers were lack of sufficient technical knowledge and skill on high tech production and post-harvest handling of cut flowers. The other problems were lack of infrastructural support for postharvest handling of cut flowers and non-availability of regular and reliable export oriented market information services.

As a result of the study conducted, it can be seen that gender, age and education level have a significant role in acquiring floriculture practice as a profession. It is also seen that mostly men prefer taking it up. Like all other profession, even floriculture is male dominated. This is the result of a patriarchal society structure and lesser freedom for women to participate in the family's economic wellbeing.

\section{REFERENCES}

[1] Acharya, B. K. \& Sharma, G. (2013). Forests and Biodiversity. In S Kharel, \& J. W. Bhutia (Eds.), Gazetteer of Sikkim, 50-54. Government of Sikkim.

[2] Agoramoorthy, G., \& Hsu, M. J. (2012). Impact of floriculture development enhances livelihood of India's rural women. Journal of Agriculture and Rural Development in the Tropics and Subtropic, 6976.

[3] Choudhary, M. L. (2008). Flowers for Trade. In V. L. Sheela (Ed.), Flowers for Trade, 10, 17-32. New Delhi: New India Publishing Agency.

[4] Joseph, G. M., Suguna, A., Tirkey, A., Kumar, N., Shanbhag, D., \& Joseph, B. (2016). A Cross-Sectional Study on the Morbidity Profile of Floriculture Workers in Selected Villages in Rural Banglore, India. International Journal of Current Research and Academic Review, 4(4), 193-199.

[5] Karthikeyan, C., \& Chandrakandan, K. (2000). Profile and problems of cut flower growers. Madras Agricultural Journal, 87(7), 500-503. 
[6] Lin, Y. J., \& Wang, T. H. (1991). The operation and management of a flower farm. Taichung district Agricultural Improvement Station, 25, 239-248.

[7] Horticulture \& Cash Crops Development Department. (2018). White Paper on 23 Years of Development Under Horticulture Sector, 199495 to 2016-17. Gangtok: Government of Sikkim.

[8] Barman, D. (2010). Cymbidium. In R. Avasthe, Y. Pradhan, \& K. Bhutia (Eds.), Handbook of Organic Production in Sikkim, $1^{\text {st }}$ ed., 259-275. Gangtok: Sikkim Organic Mission, ICAR \& Government of Sikkim.

[9] Barman, D., \& Patil, M. (2014). Carnation. In R. Avasthe, Y. Pradhan, \& K. Bhutia (Eds.), Handbook of Organic Crop Production in Sikkim, $1^{\text {st }}$ ed., 247-258. Gangtok: Sikkim Organic Mission, ICAR \& Government of Sikkim.

[10] Barman, D., Rajkumar, \& Pokhrel, H. (2014). Alstromeria. In R. Avasthe, Y. Pradhan, \& K. Bhutia (Eds.), Handbook of Organic Crop Production in Sikkim, $1^{\text {st }}$ ed., 291-296. Gangtok: Sikkim Organic Mission, ICAR \& Government of Sikkim.

[11] Bhutia, K., Pradhan, Y., Avasthe, R., \& Bhutia, P.T. (2014). Agriculture in Sikkim: Transition from Traditional to Organic Farming. In R. Avasthe, Y. Pradhan, \& K. Bhutia (Eds.), Handbook of Organic Crop Production in Sikkim, $1^{\text {st }}$ ed., 5-12. Gangtok: Sikkim Organic Mission, ICAR \& Government of Sikkim.

[12] Pokhrel, H., Rajkumar, \& Barman, D. (2014). Lily. In R. Avasthe, Y. Pradhan, \& K. Bhutia (Eds.), Handbook of Organic Crop Production in Sikkim $1^{\text {st }}$ ed., 287-290. Gangtok: Sikkim Organic Mission, ICAR \& Government of Sikkim.

[13] Horticulture and Cash Crops Development Department. (2016). Revolution in Horticulture, Sikkim's 22 years of Achievement, $1^{\text {st }} \mathrm{ed}$., Gangtok: Government of Sikkim.

[14] Kharel, S., \& Bhutia, J. W. (2013). Gazetteer of Sikkim, $1^{\text {st }}$ ed., Gangtok: Government of Sikkim.
[15] Jawaharlal, M., Ganga, M., Padmadevi, K., Jegadeeswari, V., \& Kathikeyan, S. (2012). A Technical Guide on Carnation. Department of Floriculture and Landscaping, Tamil Nadu, 1-54.

[16] Mishra, D., \& Ghosh, S. (2016). Growth and export status of Indian Floriculture: A review. Agricultural Research Communication Centre, 77-80.

[17] Rajagopal. (2015). Rural Marketing System in the North-eastern States: Diagnosis and Strategy. ASCI Consultancy, 1-190. New Delhi.

[18] Iim, F., Nabeegh, S. V., \& Qing, H. (2014). The progress and issues in the Dutch, Chinese and Kenyan floriculture industries. International Journal of Horticulture and Floriculture, 2(1), 033-039.

[19] Samoila, C. M. S. (2012). Preliminary Study of Flower Market Research through Questionnaires. Bulletin UASVM Horticulture, 69(2), 288-294

[20] Suryavanshi, N., \& Parvez, R. (2017). Major problems of flower harvesters in Allahabad city, India. International Journal of Horticulture and Floriculture, 5(3), 272-275.

[21] Janko, A. M., \& Alemu, Gosa. (2017). Supply and marketing of floriculture in Ethiopia. International Journal of Horticulture and Floriculture, 5(3), 258-271.

[22] Erdogan, E. M. (2016). Demographic factors in procuring ornamental plants marketing as a career. International Journal of Horticulture and Floriculture, 4(1), 208-216.

[23] Pique, B. (2014). Demographic factors affecting the acquisition of ornamental plants marketing as a profession. International Journal of Horticulture and Floriculture, 2(2), 052-060.

[24] APEDA. apeda.gov.in. Retrieved from www.apeda.gov.in/apeda website/SubHead_Products/Floriculture.htm

[25] Evers, B., Amoding, F., \& Krishnan, A. (2014). Social and economic upgrading in floriculture global value chains: flowers and cuttings GVCs in Uganda. Capturing the Gains Working Paper June 2014. Manchester: University of Manchester. 